\title{
Imperialism as the Last Stage of Capitalism
}

Ever since the publication of Kautsky's main writings on imperialism, he has been criticised for his characterisation of imperialism as only one possible alternative to the future development of capitalism. An early and perhaps the best-known critique came from Lenin, who criticised Kautsky for his exclusively political definition of imperialism. In this respect, one can agree with John H. Kautsky's interpretation of Karl Kautsky's theory of imperialism as presented in his article on Schumpeter and Kautsky:

Whether Kautsky inclined to the Schumpeterian 'pre-industrial' or the Hilferdingian 'industrial' explanation of imperialism certain elements of his thought remained constant; it was banking capital rather than industrial capital in its pure form that was a driving force, if not the driving force, of imperialism ... and finally, imperialism was merely one possible form of the general and inevitable phenomenon of industrial expansionism into agrarian areas and hence was not necessary to capitalism. ${ }^{1}$

The same argument was presented even more forcefully by Rainer Kraus:

Since the 1880 s, the essential feature of Kautsky's theory of imperialism consisted in attempting to demonstrate the groundlessness of virtually all arguments in favour of colonial expansion, in as far as these arguments were prejudiced by the view that colonies were necessary for the survival of capitalist society. ${ }^{2}$

Even though Kautsky did not simply think of imperialism as being an atavism in capitalism caused by pre-capitalist remnants in society, and even though Kautsky's theory is not in this respect identical to that of J.A. Hobson, Joseph Schumpeter and Emil Lederer, as claimed by Gottschalch, ${ }^{3}$ it is true that Kautsky understood imperialism as being more of an exception in the normal development of capitalism. Or rather, imperialism is both a permanent problem

1 John H. Kautsky 1961, p. 118.

2 Kraus 1978, p. 171.

3 Gottschalch 1962, p. 89. 
caused by the unequal development of industrial and agrarian production and a politically avoidable problem to be eliminated as soon as the power of finance capital could be eliminated.

As stated earlier, Kautsky's conception of imperialism resembled that of Lenin's in many respects. To both of them, imperialism is a consequence of the centralisation and monopolisation of capital and the formation of cartels and trusts. Furthermore, the centralisation of capital is a necessary feature of capitalism. Another characteristic feature of imperialism is the power and domination of finance capital over industrial capital, and the importance of the export of capital compared with the export of commodities. Kautsky's emphasis on the role of protective tariffs did not, on the other hand, figure in Lenin's analysis - a fact already indicating that Kautsky, more so than Lenin, analysed imperialism as a concrete historical form of the economic policy of the state. Neither did the idea of the difference and conflict between agrarian and industrial countries and production explain the annexation of colonies and their economic importance to Lenin - even though it was also mentioned by Lenin. For Kautsky, this difference was the most important single cause of imperialistic policy. The main and decisive difference, however, is that whilst Kautsky understood imperialism as a specific political method of guaranteeing the profits of capital, Lenin also considered imperialism as being a specific and necessary stage in the economic development of capitalism.

To Lenin, the future of capitalism was by nature necessarily violent; it represented the repression of the people and led to the stagnation of productive forces and repressive methods of government. In the analysis of imperialism of both Kautsky and Lenin, there was, however, one more important common characteristic: power is the new decisive factor in imperialism, and relations of power and dominance replace relations of a purely economic character in imperialism.

In defining imperialism as the monopolistic phase of capitalism, Lenin did not yet differ essentially from Kautsky's analysis. Neither Kautsky nor Lenin discussed in any great detail the nature of the transformation of free competition into monopolistic competition. They simply stated that monopolistic competition - to a certain extent - takes the place of free competition and that this transformation is made possible by the centralisation of capital - at least in the internal market. It must nevertheless be admitted that Lenin discussed the relation between free competition and monopolistic competition in more detail than Kautsky. To Kautsky, the monopolistic organisations were simply the most influential power organisations in a society realising their interests in state policy. Kautsky did not formulate any explicit conception of competition in capitalism. 
According to Lenin, monopoly is the economic essence of imperialism. However, this definition must be complemented by a list of other defining characteristics of imperialism:

And so ... we must give a definition of imperialism that will include the following five of its basic features: 1) the concentration of production and capital has developed to such a high stage that it has created monopolies which play a decisive role in economic life; 2) the merging of bank capital with industrial capital, and the creation, on the basis of this 'finance capital', of a financial oligarchy; 3 ) the export of capital as distinguished from the export of commodities acquires exceptional importance; 4) the formation of international monopolist capitalist associations which share the world among themselves; and 5) the territorial division of the whole world among the biggest capitalist powers is completed. ${ }^{4}$

Having presented the above list, Lenin was ready to formulate a 'more complete' definition of imperialism:

Imperialism is capitalism at the stage of development at which the dominance of monopolies and finance capital is established; in which the export of capital has acquired pronounced importance; in which the division of the world among the international trusts has begun, in which the division of all territories of the globe among the biggest capitalists has been completed. ${ }^{5}$

Immediately after presenting his own 'definition' of imperialism, Lenin criticised Kautsky's conception. According to Lenin, Kautsky made two grave mistakes in his analysis of imperialism. To begin with, Kautsky's conception of imperialism was restricted to a certain specific political method of capitalist states. The second mistake was that Kautsky emphasised imperialism as being equivalent to the method of annexation of colonies. Kautsky's definition of imperialism as a specific political form or method of capitalist states was as such correct but, in Lenin's opinion, incomplete. Kautsky forgot that imperialism is essentially reactionary and violent by nature. At least in this respect Lenin's critique of Kautsky was, however, misdirected. On several occasions, Kautsky stated explicitly that imperialism is reactionary and violent in char-

4 Lenin 1967d, pp. 745-6.

5 Lenin 1967d, p. 746. 
acter. Lenin's critique of the economic causes of imperialism as formulated by Kautsky was, however, more adequate. According to Lenin, Kautsky was mistaken in indentifying the causes of imperialism with the complex and problematic relation between industrial and agrarian capital. Imperialism cannot be adequately characterised as representing the interests of industrial capital in enlarging the market for its products; the dominating form of capital in imperialism is finance capital. Furthermore, the annexation of agrarian areas or countries as colonies of industrial states is not as such typical only of imperialism. Imperialism is, on the contrary, characterised by the struggle for hegemony over industrial countries as well. ${ }^{6}$

Kautsky's main failure in analysing imperialism, however, was that in distinguishing between political and economic factors in imperialism, he claimed that there is possibly another kind of policy in modern capitalism which would satisfy the interests of industrial capital, as well as imperialism, and which would not be violent and reactionary in character. ${ }^{7}$ Lenin's conclusion in his critical analysis of Kautsky's conception of imperialism was that Kautsky had become a reformist and an enemy of Marxism:

The result is a slurring over and a blunting of the most profound contradictions of the latest stage of capitalism, instead of an exposure of their depth; the result is bourgeois reformism instead of Marxism. ${ }^{8}$

The main target of Lenin's critique was Kautsky's concept of ultra-imperialism. Lenin admitted in principle that the economic development of capitalism would lead to the formation of a single worldwide trust. On one occasion, Lenin even referred to the possible formation of a super-monopoly. ${ }^{9}$ But such a prophecy would be totally devoid of any interest. ${ }^{10}$ Compared with the actual development of the world economy at the beginning of the century, the conception of ultra-imperialism could be shown to contradict the actual state of affairs. Kautsky's conception was, after all, dangerous. It lent support to the legitimation of imperialism in emphasising the possibility of a non-contradictory development of capitalism. According to Kautsky, capitalism can develop without crises; in reality, imperialism sharpens these contradictions and increases the occurrence of crises in capitalism:

\footnotetext{
Lenin 1967d, pp. 746-8.

Lenin 1967 d, p. 748.

Lenin 1967 d, pp. $748-9$.

Lenin 1967 , p. 728 .

Lenin 1967 d, p. 750 .
} 
Are not the international cartels which Kautsky imagines are the embryos of 'ultra-imperialism' ... an example of the division and the redivision of the world, the transition from peaceful division to non-peaceful division and vice versa?11

And further:

Finance capital and the trusts do not diminish but increase the differences in the rate of growth of the various parts of the world economy. Once the relation of forces is changed, what other solution of the contradictions can be found under capitalism than that of force? ${ }^{12}$

As Lenin stated, it is exactly the characterisation of imperialism as only one specific and possible form of the politics of a capitalist state that does not pay any attention to the fact that imperialism is a necessary consequence of the development of capitalism which marks the main difference between their conceptions. ${ }^{13}$ Lenin did not approve of Kautsky's 'deduction' of imperialism from the different conditions of industrial and agrarian production. On the other hand, he did not pay attention to the fact that Kautsky repeatedly mentioned both monopolisation and the dominance of finance capital as the main causes of imperialism too. The main target of his critique was quite obviously and repeatedly not so much the fact that Kautsky did not understand the economic 'essence' of imperialism (imperialism as monopolistic capitalism). Kautsky was to be criticised mainly because his analysis led to the dangerous conclusion that imperialism can develop into a new stage of peaceful and non-aggressive capitalism. It is exactly this conclusion that made Kautsky's conception essentially a reformist one, to be criticised as such. ${ }^{14}$

11 Lenin 1967 d, pp. $75^{1-2 .}$

12 Lenin 1967 d, p. $75^{2}$.

13 This major difference in the interpretations of the essential nature of imperialism was already explicitly formulated by Karl Radek in the article 'Our Struggle Against Imperialism' ['Zum unseren Kampf gegen den lmperialismus']: 'The foundation of all the differences in our relationship to imperialism is the question of its character. What is imperialism, and what is its relationship to capitalist development in general and to worldeconomic expansion in particular? Is it the foreign policy of crashing capitalism, or simply one of the forms still possible for capitalist display of power?' (Radek 2011, p. 543). Radek's own answer to the question is obvious: 'Imperialism is the only possible world policy of the present capitalist era' (Radek 2011, p. 549). 
On the other hand, there is, in fact, not such a big difference between Lenin and Kautsky in their evaluations of the consequences of imperialism for the future of capitalism. According to both of them, imperialism leads to the application of violent methods in politics and militarism at home and in foreign relations. In Lenin's opinion: 'domination, and the violence that is associated with it, such are the relationships that are typical of the "latest phase of capitalist development".'. ${ }^{15}$ Democratic methods of government are displaced by repressive and reactionary ones; economic competition as the regulatory principle of capitalism is displaced by the power and dominance of finance capital. Imperialism further leads to the stagnation of productive forces and the sharpening of crisis development both internationally and nationally. Lenin's conception of the consequences of imperialism for the economic progress of capitalism did not markedly differ from Kautsky's corresponding formulations. Kautsky would accept all the conclusions drawn by Lenin too:

As we have seen, the deepest economic foundation of imperialism is monopoly. This is capitalist monopoly, i.e. monopoly which has grown out of capitalism and which exists in the general environment of capitalism, commodity production and competition, in permanent and insoluble contradiction to this general environment. Nevertheless, like all monopoly, it inevitably engenders a tendency of stagnation and decay. Since monopoly prices are established, even temporarily, the motive cause of technical and, consequently, of all other progress disappears to a certain extent and, further, the economic possibility arises of deliberately retarding technical progress. ${ }^{16}$

However, Kautsky's most serious mistake - according to Lenin - was in imagining that capitalism would develop more rapidly and more effectively if free competition were re-established and it were not restricted by monopolies or finance capital. Lenin claimed that even though it might be presupposed that capitalism would develop more rapidly under the conditions of free competition, this presupposition is completely abstract. Kautsky forgot that the very development of capitalism necessarily gives rise to the permanent monopolisation and centralisation of capital:

(read: Marxism-Leninism) and revisionism in Kautsky's thinking about imperialism, see Braionovich 1982, pp. 181-8; see also Braionovich 1979, pp. 208-19.

15 Lenin 1967 d, p. 694.

$16 \quad$ Lenin 1967 d, p. 754 . 
And monopolies have already arisen - precisely out of free competition! Even if monopolies have now begun to retard progress, it is not an argument in favour of free competition, which has become impossible after it has given rise to monopoly. ${ }^{17}$

In other words, Kautsky did not understand that the process of monopolisation is an unavoidable result of capitalist development and as such an irreversible process. And because of this mistake, Kautsky became a reactionary and a reformist. ${ }^{18}$

In Lenin's analysis, imperialism was not only the necessary consequence of capitalist development, it was also the immediate predecessor of socialism. There is no other alternative to imperialism but socialism, and on the other hand, the preconditions for socialism practically ripen in imperialism. These conclusions are already included in the very definition of imperialism as monopoly capitalism:

This in itself determines its place in history, for monopoly that grows out of the soil of free competition, and precisely out of free competition, is the transition from the capitalist system to a higher socio-economic order. ${ }^{19}$

Imperialism is thus the immediate transitory stage from capitalism to socialism which determines its place in human history:

From all that has been said in this book on the economic essence of imperialism, it follows that we must define it as capitalism in transition, or, more precisely, as moribund capitalism. ${ }^{20}$

The development of capitalism into imperialism was thus argued by Lenin to be an inevitable and irreversible consequence of the economic development of capitalism. The contradictions of capitalism are furthermore accentuated in imperialism. According to Lenin, the relations of private property which are preserved intact even in imperialism no longer correspond to its relations of production: 'Production becomes social, but appropriation remains private..21

\footnotetext{
17 Lenin 1967d, p. 765 .

18 Ibid.

19 Lenin $1967 \mathrm{~d}$, pp. $77^{-2} 3$.

$20 \quad$ Lenin 1967 d, pp. $775^{-6}$.

21 Lenin 1967d, p. 693.
} 
Thus Lenin seemed to round off his argumentation of the consequences of imperialism following Engels's formulation of the basic contradiction of capitalism, which Kautsky had also taken as his own. But in Lenin's analysis, this basic contradiction took a new form and was even accentuated in imperialism. Due to the monopolisation of production, 'the social means of production remain the private property of a few'22 (even fewer than before). And in imperialism, the contradiction between private appropriation and the socialisation of production becomes even more accentuated as the contradiction between 'formally recognised free competition' and factual 'monopolistic competition'. As a consequence, 'the yoke of a few monopolists on the rest of the population becomes a hundred times heavier, more burdensome and intolerable.' ${ }^{23}$ In imperialism, the basic contradiction of capitalism is developed to its utmost form, and consequently, the relations of private property must give way to a socialisation of the means of production which recognises that the means of production are, in fact, already in capitalism, social means of production.

22 Ibid.

23 Ibid. 